\title{
Colorectal cancer development and advances in screening
}

\author{
This article was published in the following Dove Press journal: \\ Clinical Interventions in Aging \\ 19 July 2016 \\ Number of times this article has been viewed
}

\author{
Karen Simon \\ Ventura County Gastroenterology \\ Medical Group, Inc., Camarillo, \\ CA, USA
}

\begin{abstract}
Most colon tumors develop via a multistep process involving a series of histological, morphological, and genetic changes that accumulate over time. This has allowed for screening and detection of early-stage precancerous polyps before they become cancerous in individuals at average risk for colorectal cancer (CRC), which may lead to substantial decreases in the incidence of CRC. Despite the known benefits of early screening, CRC remains the second leading cause of cancer-related deaths in the United States. Hence, it is important for health care providers to have an understanding of the risk factors for CRC and various stages of disease development in order to recommend appropriate screening strategies. This article provides an overview of the histological/molecular changes that characterize the development of CRC. It describes the available CRC screening methods and their advantages and limitations and highlights the stages of CRC development in which each screening method is most effective.
\end{abstract}

Keywords: colorectal cancer, DNA test, polyps, screening

\section{Introduction}

Screening for colorectal cancer (CRC) has substantially contributed to the downward trends in CRC incidence and mortality over the last 2 decades. ${ }^{1,2}$ The clinical value of screening is reflected in its ability to prevent cancer morbidity, mortality, and excess treatment cost by detecting significant lesions before they become cancerous and early-stage cancer before it spreads beyond the bowel wall. The 5-year survival rates for those with early-stage, localized disease (Stages I and II) approach $90 \%{ }^{2}$ The survival rate for those diagnosed with late-stage CRC, which is associated with spread to distant organs, is $13.1 \%$. At this stage, treatment often becomes palliative and treatment-related financial burdens are the greatest. ${ }^{1,3}$

Despite the well-known benefits of screening and recommendations for averagerisk adults aged 50 years and older to be screened, CRC is the second leading cause of cancer-related death among both men and women and contributes $\sim \$ 14$ billion to annual health care costs in the US, an expenditure that continues to increase..$^{4,5}$ Screening may help control the costs of CRC treatment, as most screening strategies have become cost saving relative to increasing costs associated with chemotherapy for advanced CRC. ${ }^{6}$ At present, only $65 \%$ of US adults are in compliance with current screening recommendations. ${ }^{7}$ The National Colorectal Cancer Roundtable has a goal of increasing screening rates to $80 \%$ by 2018 . It is estimated that achieving this goal will avert 280,000 new cases of CRC and save 200,000 lives in the US by 2030. . $^{8}$ Discussions of CRC screening with patients that lead to successful screenings will be of vital importance to achieving this goal. ${ }^{7}$ This review provides a concise overview 
of the risk factors for CRC, the histological and molecular changes that characterize the development of $\mathrm{CRC}$, and a discussion of screening methods.

\section{Risk factors for CRC}

Although anyone can develop CRC, several factors are associated with an increased risk for the disease. Some risk factors are modifiable, such as diet, obesity, lack of physical activity, tobacco use, and moderate-to-heavy alcohol use. Conversely, higher intakes of dietary fiber, green leafy vegetables, folate, and calcium have been reported to be protective against the development of CRC. ${ }^{2}$ Although modification of these factors may result in a decreased risk for CRC, no effect of modification is sufficient to reduce the need for screening. ${ }^{1}$ Other risk factors are nonmodifiable, such as a personal or familial history of colorectal polyps or CRC, hereditary conditions such as Lynch syndrome, a personal history of inflammatory bowel disease, racial and ethnic backgrounds, and the presence of type 2 diabetes. ${ }^{1,2,4}$ Although CRC can occur in early- to mid-adulthood, particularly in those with certain inherited predispositions, most cancer occurs in persons considered as average risk, and age is the most significant risk factor in this group. ${ }^{4}$ The chance of developing CRC increases markedly after age 50 years, with $90 \%$ of new cases and $94 \%$ of CRC-associated deaths occurring in those $\geq 50$ years of age. ${ }^{1}$ Screening persons of average risk who are $\geq 50$ years of age and closely monitoring those individuals at higher risk provide the best opportunity for prevention and early detection of CRC. The high-risk designation includes individuals with personal or familial history of CRC, adenomatous polyps, inflammatory bowel disease, and hereditary CRC syndromes; high-risk individuals should consult with their health care provider to determine when to begin screening and how often to repeat the screening. ${ }^{2}$

\section{Development of CRC}

Underscoring the need for screening, CRC often grows slowly, and generally does not produce symptoms until reaching a considerable size of several centimeters, which may block the passage of feces and lead to cramping, pain, or bleeding that can present as visible bleeding with bowel movements or, rarely, dark "tarry" stools. Most colon tumors develop via a multistep process involving a series of histological, morphological, and genetic changes that accumulate over time. ${ }^{10}$ The various stages of CRC progression, along with their accompanying histological, morphological, and genetic changes, are outlined later and in Figure 1.

\section{Polyps}

CRC typically develops from focal changes within benign, precancerous polyps. These polyps are localized growths or aggregations of abnormal cells within the intestinal mucosa that protrude into the intestinal lumen. ${ }^{1}$ Polyps can be sessile (Figures 1A and 2A) or pedunculated (Figures 1A and 2B). ${ }^{4}$ With time, the dividing cells in these polyps may accumulate sufficient genetic changes by which they acquire the ability to invade the bowel wall, the hallmark of CRC, and eventually may become more altered and spread to local lymph nodes and finally to distant metastatic sites. ${ }^{1}$ Fortunately, only a small percentage of polyps acquire malignant features, and even for the ones that do, the complete progression from polyps to cancer generally takes several years or even a decade. ${ }^{11}$

There are two main types of polyps with malignant potential, adenomas and sessile serrated polyps (SSPs), each of which are associated with different risks for developing into CRC. In general, most adenomas have a tubular histology with small, roundish, atypical glands but often develop areas of long filamentous architecture as they grow, which is described on pathology reports as villous or tubulovillous. By definition, adenomas are characterized by dysplasia (low degree of cellular and structural atypia). Tubulovillous and villous adenomas, especially those with $\geq 25 \%$ villous content, are typically larger in size and have a greater potential for harboring cancerous cells. In contrast, SSPs are flat and carpet like, with serrated or saw-toothed glands. SSPs include sessile serrated adenomas, traditional serrated adenomas, and mixed polyps, which have all been associated with CRC development. ${ }^{12,13}$

The risk for adenomas to develop into CRC increases as the size of the polyp increases. ${ }^{12}$ Although only $~ 10 \%$ of even the most advanced adenomas (adenomas $\geq 1 \mathrm{~cm}$ in size or that have $\geq 25 \%$ villous component or high-grade dysplasia of any size) become cancerous, $60 \%-70 \%$ of CRCs develop from adenomas. The remaining $25 \%-35 \%$ of CRCs develop from SSPs. ${ }^{13-15}$

Polyps can develop along the entire length of the colon and rectum; however, polyps that develop within the proximal (right) side of the colon, which includes the cecum through the transverse colon up to and including the splenic flexure, account for $42 \%$ of all CRCs in the US. ${ }^{16}$ Proximal polyps are often the SSP type and can be difficult to detect as they are often flattened or depressed and may not bleed or ulcerate. ${ }^{12}$

\section{Progression from polyp to cancer: histological and morphological changes}

The histological changes that occur during the development of CRC are outlined in Figure 1A. As the cells within 


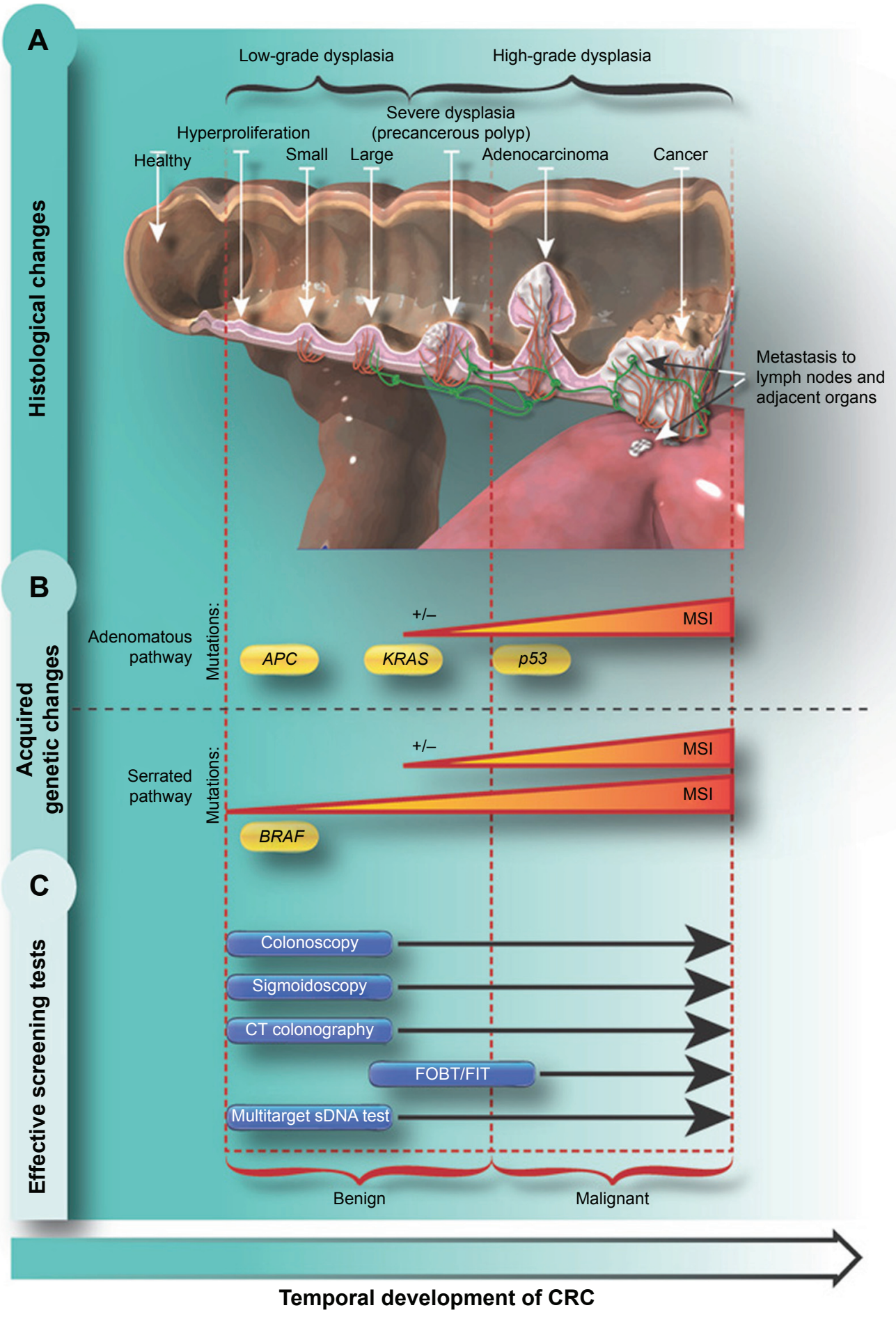

Figure I CRC development and screening methods.

Notes: (A) Histological changes of CRC; (B) acquired genetic changes of CRC; (C) effective screening tests for CRC. The temporal development of CRC is indicated from left to right in each panel. Includes methylation of BRAF, KRAS, BMP3, and NDRG4 genes. Data from O'Brien et al..$^{28}$

Abbreviations: CRC, colorectal cancer; CIMP, CpG island methylator phenotype; CT, computed tomography; FOBT, fecal occult blood test; FIT, fecal immunochemical test; MSI, microsatellite instability; sDNA, stool DNA.

the polyp proliferate, the size of the polyp increases, and genetic mutations and epigenetic changes may begin to accumulate; this is reflected by cytologic and histologic dysplasia. ${ }^{10,17}$ As damage to cellular DNA increases over time, the features of high-grade dysplasia may develop, which connotes a very high degree of risk for progression to invasive carcinoma. ${ }^{10}$ If not removed, these polyps may develop the ability to invade nearby tissue and grow into and beyond the wall of the colon and rectum. This localized, malignant growth may become neovascularized, 

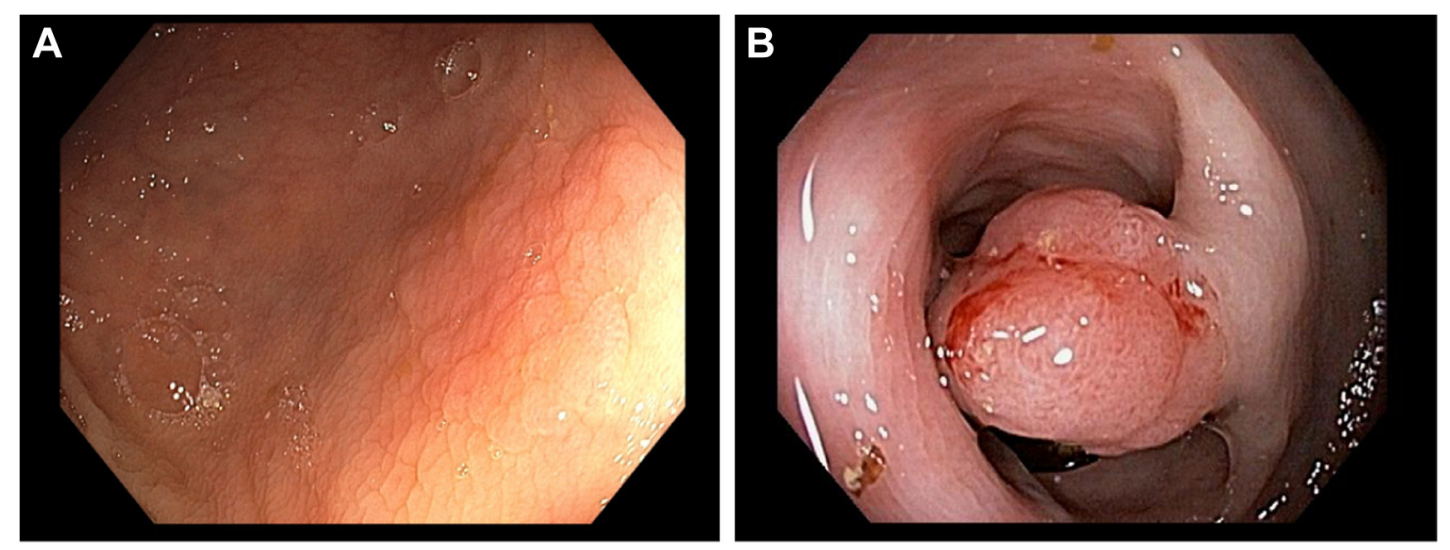

Figure 2 Polyps.

Notes: (A) Flat, serrated polyp. (B) Pedunculated polyp. Photos courtesy of Louis M. Wong Kee Song, MD, Professor of Medicine, Division of Gastroenterology, Mayo Clinic.

thus providing easy access to the lymph and circulatory systems and thereby promoting the spread of cancerous cells to distant organs. ${ }^{10,18}$ Early detection and resection of precancerous polyps are critical to interrupt the adenomacarcinoma sequence and prevent the development and spread of CRC.

\section{Progression from polyp to cancer: genetic changes}

The histological progression from polyp to cancer is the result of a series and/or accumulation of genetic and epigenetic changes. DNA mutations can be acquired or inherited. True inherited mutations associated with CRC, such as the $M L H 1$, MSH2, PMS2, and the $A P C$ gene mutations, are uncommon and account for $\sim 5 \%$ of CRCs. However, studying these inherited mutations, in addition to sporadically occurring $A P C$ and DNA mismatch repair mutations, has provided key insights into the stepwise genetic progression from premalignant polyps to cancer. ${ }^{18-20}$

There are two main genetic pathways that lead to the development of CRC (Figure 1B). ${ }^{21}$ These generally correspond with the two types of polyps from which CRC develops: adenomas and SSPs. The chromosomal instability pathway, generally associated with traditional adenomas, is observed in $65 \%-70 \%$ of all sporadic cancers and is characterized by a cascade of accumulating mutations. Typically, the first mutations that develop are within the $A P C$ gene, which affects chromosome segregation during cell division. Subsequent mutations then develop in the KRAS oncogene, which has downstream effects on cell growth, differentiation, motility, and survival. Over time, these mutations can cause a loss of function of the $p 53$ gene, which is a master regulator of transcription and apoptosis, thus impacting a wide range of cellular functions that ultimately results in carcinogenesis. ${ }^{22}$

In contrast, development of SSPs tends to begin with mutations in the BRAF gene, which results in altered growth signaling and loss of apoptosis. ${ }^{13,21,23,24} \mathrm{KRAS}$ mutations can also occur in SSPs, but they are much less frequently associated with SSPs than adenomatous polyps. ${ }^{21,23}$ Another common epigenetic alteration seen in serrated lesion-based CRC is aberrant gene promoter region hypermethylation. Promoter region methylation inhibits gene transcription, functionally turning affected genes "off". This gene deactivation impacts many genes including those regulating other growth-promoting genes. ${ }^{23}$ Aberrantly methylated genes associated with $\mathrm{CpG}$ island methylator phenotype include, among others, the bone morphogenic protein $3(B M P 3)^{25}$ and N-Myc downstreamregulated gene $4(N D R G 4))^{25,26}$

Another mechanism that leads to genetic diversity in CRC is microsatellite instability (MSI), which is caused by the disruption of DNA repair genes. MSI can result in uneven replication of repetitive DNA sequences in short, noncoding regions (microsatellites) and increased susceptibility to additional genetic mutations. . $^{13,21,23,27,28}$ MSI can occur in both adenomatous and serrated polyps and is associated with germline mutations in DNA mismatch repair genes (eg, in hereditary nonpolyposis colorectal cancer) as well as sporadic mutations due to aberrant methylation of the $M L H 1$ promoter regions (associated with $\mathrm{CpG}$ island methylator phenotype). ${ }^{13,23,27,29}$

\section{Current screening options for CRC}

There are several different screening tests for the detection of $\mathrm{CRC}$, each of which has advantages and limitations. 
The individual features of each test also affect patient and physician perceptions and preferences, which in turn can affect the informed decision-making process in choosing the appropriate screening test. The most important characteristic of a screening test is its sensitivity (the true-positive rate), which is the percentage of patients with the disease who get a positive result with the test. Also important, but less so than sensitivity, is reasonably high specificity, which is the percentage of patients without disease who receive a negative result (also known as the true-negative rate). Together, sensitivity and specificity define the accuracy of a test, and they are generally traded off against each other depending on the clinical situation. When missing a lesion or disease state has the potential for severe or grave consequences, sensitivity is favored over specificity. When the chance of harm from overtreatment is of greatest concern, specificity is favored over sensitivity. In many screening applications, a more specific test may follow a more sensitive test, but a single test with both high sensitivity and high specificity is preferred. ${ }^{30}$ High accuracy for detecting CRC is critical, as false-positive results would cause unnecessary anxiety and follow-up, whereas false-negative results would result in missed detection of CRC. In addition, the test should be precise, providing consistent results when repeated. Individuals who need to be screened are often asymptomatic, and achieving a high rate of cooperation from such individuals is necessary for an effective screening program; therefore, the test should be acceptable from the individual's perspective. The test should be easy to administer and use, be easily accessed, have minimal out-of-pocket expenses, and be safe to encourage high participation in screening efforts. ${ }^{30}$ Here, we provide a brief description of the common CRC screening methods, their advantages and limitations, and where in the process of CRC development they are most effective (Figure 1C and Table 1).

\section{Colonoscopy}

Colonoscopy is the current reference method for CRC screening and is recommended every 10 years in average-risk patients aged 50 years or older. ${ }^{31}$ The ability of colonoscopy

Table I CRC screening tests

\begin{tabular}{|c|c|c|c|c|c|}
\hline Test & Premise & $\begin{array}{l}\text { Sensitivity } \\
\text { for CRC }\end{array}$ & $\begin{array}{l}\text { Screening } \\
\text { interval }\end{array}$ & Advantages & Limitations \\
\hline Colonoscopy & $\begin{array}{l}\text { Endoscopic examination } \\
\text { of the entire colon }\end{array}$ & $>95 \%$ & Every 10 years & $\begin{array}{l}\text { High sensitivity, allows } \\
\text { visualization of full colon, } \\
\text { detection of distal and } \\
\text { proximal lesions, can remove } \\
\text { lesions at time of detection }\end{array}$ & $\begin{array}{l}\text { Invasive, unpleasant bowel } \\
\text { preparation, requires special } \\
\text { facilities and sedation, } \\
\text { cost, accessibility, need } \\
\text { for anesthesia, low patient } \\
\text { compliance, risk of bowel } \\
\text { perforation or bleeding }\end{array}$ \\
\hline Sigmoidoscopy & $\begin{array}{l}\text { Endoscopic examination } \\
\text { of the distal colon }\end{array}$ & $\begin{array}{l}>95 \% \text { (distal } \\
\text { colon only) }\end{array}$ & $\begin{array}{l}\text { Every } 5 \text { years } \\
\text { in combination } \\
\text { with FOBT }\end{array}$ & $\begin{array}{l}\text { High sensitivity (distal colon } \\
\text { only), full sedation not } \\
\text { required, can remove lesions } \\
\text { at time of detection }\end{array}$ & $\begin{array}{l}\text { Semi-invasive, unpleasant bowel } \\
\text { preparation, requires special } \\
\text { facilities and sedation, cost, } \\
\text { accessibility, only screens distal } \\
\text { colon, safety concerns, patient } \\
\text { discomfort }\end{array}$ \\
\hline CT colonography & $\begin{array}{l}\text { Radiologic visualization } \\
\text { of the colon, aka virtual } \\
\text { colonoscopy }\end{array}$ & $>90 \%$ & Every 5 years & $\begin{array}{l}\text { High sensitivity, allows } \\
\text { visualization of full colon, no } \\
\text { sedation needed, detection } \\
\text { of distal and proximal lesions }\end{array}$ & $\begin{array}{l}\text { Semi-invasive, unpleasant } \\
\text { bowel preparation, requires } \\
\text { special facilities, cannot remove } \\
\text { lesions at time of detection, } \\
\text { radiological safety concerns }\end{array}$ \\
\hline FOBT & $\begin{array}{l}\text { Enzymatic detection of } \\
\text { hemoglobin in the stool }\end{array}$ & $33 \%-75 \%$ & Annually & $\begin{array}{l}\text { Accessibility, noninvasive, } \\
\text { low cost, detection of distal } \\
\text { and proximal CRC }\end{array}$ & $\begin{array}{l}\text { Poor detection of precancerous } \\
\text { lesions, cannot remove lesions } \\
\text { at time of detection, detects } \\
\text { ingested hemoglobin }\end{array}$ \\
\hline FIT & $\begin{array}{l}\text { Immunochemical } \\
\text { detection of } \\
\text { hemoglobin in the stool }\end{array}$ & $60 \%-85 \%$ & Annually & $\begin{array}{l}\text { Accessibility, noninvasive, } \\
\text { low cost, detection of distal } \\
\text { and proximal CRC }\end{array}$ & $\begin{array}{l}\text { Poor detection of precancerous } \\
\text { lesions, cannot remove lesions } \\
\text { at time of detection }\end{array}$ \\
\hline mt-sDNA test & $\begin{array}{l}\text { Molecular detection of } \\
\text { DNA aberrations and } \\
\text { hemoglobin }\end{array}$ & $92 \%$ & Every 3 years & $\begin{array}{l}\text { High sensitivity, accessibility, } \\
\text { noninvasive, detection of } \\
\text { proximal and distal lesions }\end{array}$ & $\begin{array}{l}\text { Better detection of cancer than } \\
\text { precancerous lesions, cannot } \\
\text { remove lesions at time of } \\
\text { detection }\end{array}$ \\
\hline
\end{tabular}

Abbreviations: CRC, colorectal cancer; CT, computed tomography; FOBT, fecal occult blood test; FIT, fecal immunochemical test; mt-sDNA, multitarget stool DNA. 
to detect both cancerous and precancerous lesions via direct visualization has been demonstrated in several large cohort studies. ${ }^{32-35}$ The sensitivity of colonoscopy for detecting CRC is $>95 \%$, while its sensitivity for detecting advanced adenomas ( $\geq 10 \mathrm{~mm}$ in diameter) is $88 \%-98 \%{ }^{33-39}$ Casecontrol studies have shown a $53 \%-72 \%$ reduction in the incidence of CRC and a 31\% reduction in CRC-related mortality with colonoscopy. ${ }^{40-42}$ Reductions in CRC incidence and mortality with colonoscopy have not been demonstrated in randomized controlled trials, nor are there trials directly comparing outcomes of colonoscopy with other screening tests. The recommended 10-year interval after a normal colonoscopy is largely based on case-control studies. ${ }^{42}$ One of the greatest advantages of colonoscopy is the ability to remove precancerous and small cancerous lesions at the time of detection. It can also assess both the proximal and distal portions of the colon. Limitations associated with colonoscopy include the invasiveness of the procedure, the required bowel preparation, the use of sedation or anesthesia, time off of work or other activities, and assistance to get home postprocedure. ${ }^{43}$ Bowel preparation is often unpleasant and time-consuming, necessitating a temporary change in medications and diet, and entails use of a cleansing agent. ${ }^{44}$ There is a risk of bowel perforation during colonoscopy and a risk of postcolonoscopy bleeding, especially in postpolypectomy patients. ${ }^{45}$ These limitations contribute to low compliance with colonoscopy screening. ${ }^{46}$ Additionally, there is a high reliance on the technical expertise of endoscopic examiners to visualize and remove lesions, especially those in the proximal colon, which can be more difficult to detect. ${ }^{11}$ Flat or sessile polyps may be especially difficult to detect and may require special techniques. ${ }^{47}$ Another limitation is the potential for "interval cancers", which are cases of CRC that occur in the long interval between normally scheduled screening colonoscopies and have been reported to account for $6 \%-9 \%$ of all CRC cases. ${ }^{48-50}$

\section{Sigmoidoscopy}

Flexible sigmoidoscopy, which is less frequently used in the US for screening, is similar to colonoscopy except that only the distal half of the colon is examined, sedation is not necessary, and the bowel preparation consists of an enema on the day of the examination. ${ }^{43}$ It has a $>95 \%$ sensitivity for the detection of CRC in the portion of the colon that is examined and a $70 \%$ sensitivity for advanced adenomas ( $\geq 10 \mathrm{~mm}$ in diameter). If lesions are identified in the distal colon, a follow-up colonoscopy is required, at which time proximal lesions may be found. ${ }^{34,51}$ Case-control studies of sigmoidoscopy have demonstrated a $60 \%$ reduction in mortality from CRCs of the distal colon, but there is little effect on reducing proximal CRC morbidity and mortality due to lack of screening in this portion of the colon. ${ }^{33,34,52}$ When used, current guidelines suggest that sigmoidoscopy should be paired with high-sensitivity fecal occult blood testing (FOBT; described later) and should be repeated every 5 years in asymptomatic individuals with no previous history of colon polyps. ${ }^{31}$

Similar to colonoscopy, the advantages of sigmoidoscopy include its ability to identify both cancerous and precancerous lesions (but only in the distal colon) and its ability to remove lesions at the time of detection. Sigmoidoscopy also shares many of the limitations of colonoscopy, including the need for bowel preparation, access to health care facilities, long waits for appointments, and safety concerns. Because the procedure is limited to the distal portion of the colon and sedation is not typically offered, sigmoidoscopy may cause considerable discomfort compared with colonoscopy under anesthesia, while leaving a large portion of the colon unscreened. ${ }^{43,53}$

\section{Computed tomography colonography}

Computed tomography (CT) colonography is a structural radiologic examination of the colon sometimes referred to as "virtual colonoscopy". It uses CT and special software to create a three-dimensional image of the colon to identify colonic lesions, which may be found on subsequent optical colonoscopy to be cancer and precancerous polyps. ${ }^{11}$ Although the sensitivity of CT colonography for detection of CRC and advanced adenomas in daily clinical practice is somewhat uncertain, clinical studies suggest that rates are $>90 \%$ for detection of CRC, $90 \%$ for detection of polyps $\geq 10 \mathrm{~mm}$, and $78 \%$ for detection of polyps $\geq 6 \mathrm{~mm} .{ }^{54}$ In the US, the reception of CT colonography as a recommended CRC screening tool is mixed, ${ }^{43,55,56}$ and its use is limited mainly to patients who are not good candidates for colonoscopy due to other comorbidities or structural issues that preclude adequate optical examination of the colon. ${ }^{43,55-57}$ However, two organizational screening studies conducted in Europe demonstrate that participation rates for CT colonography are superior to those of colonoscopy. ${ }^{58,59}$ Notably, there is no empirical evidence to demonstrate that $\mathrm{CT}$ colonography can reduce $\mathrm{CRC}$ incidence or related mortality. Although the screening interval for negative CT colonography results is uncertain, studies suggest that for average-risk, asymptomatic patients, the test should be repeated every 5 years. ${ }^{43}$ The Centers for 
Medicare and Medicaid Services currently does not pay for CT colonography as a screening test. ${ }^{60}$

Like colonoscopy, CT colonography carries the advantage of allowing visualization of the entire colon but is only semi-invasive. To facilitate better visualization, the colon is inflated with air; although this is uncomfortable for many patients, it does not require sedation. ${ }^{43}$ Limitations of CT colonography include unpleasant bowel preparation, similar to that used with colonoscopy, and the use of ionizing radiation, which imparts additional safety concerns and costs and requires access to specific health care facilities. This screening method is highly dependent on the technical expertise of the radiologist interpreting the results. CT colonography requires a follow-up colonoscopy if lesions are detected. ${ }^{61}$ Due to similar limitations, the use of double-contrast barium enema as an alternative screening method for radiologic evaluation of the colon has been largely discontinued. ${ }^{62}$

\section{FOBT and fecal immunochemical tests}

FOBT and fecal immunochemical tests (FITs) are designed to detect hemoglobin as a marker of occult blood in the stool. ${ }^{43}$ FOBT detects the peroxidase activity of heme and, as such, is not specific for human blood, whereas FIT uses human globin-specific antibodies to detect hemoglobin, so it is more specific for human blood than FOBT. ${ }^{62}$ The performance of FIT and FOBT varies due to the multiplicity of commercially available tests, different number of samples used at each testing event, and whether the studies were observational in nature or used colonoscopy to confirm the findings. Many FOBT/FIT studies are observational, which may overestimate sensitivity. ${ }^{63}$ In studies that used colonoscopy as a reference standard, the sensitivity of FIT for detecting CRC and precancerous lesions, 71\%-75\% and 27\%-29\%, respectively, was higher than FOBT, 33\%-75\% and $11 \%-25 \%$, respectively. ${ }^{56,64-66}$ The specificity of FOBT (98\%-99\%) was greater than FIT (94\%-95\%). ${ }^{56,64-66}$ FOBT has been shown to reduce CRC mortality by $15 \%-33 \%$. $^{7,69-71}$ When used as the sole screening method, FOBT and FIT should be repeated annually. ${ }^{43}$

FOBT and FIT can be performed at home, are noninvasive, and do not require extensive bowel preparation. Limitations including sporadic bleeding from lesions can lead to falsenegative test results, and lesions in early development bleed less frequently, if at all, so there is a greater tendency for these tests to detect more advanced lesions and miss precancerous lesions. ${ }^{43,53}$ In addition, dietary intake of vitamin $\mathrm{C}$ can lead to false-negative results as it can inhibit the peroxidase activity of
FOBT, and dietary hemoglobin from the ingestion of red meat can generate false-positive results on FOBT. ${ }^{11,43}$ Although FIT kits only require that the test be performed once, some FOBT tests require that the test be performed in duplicate or triplicate. ${ }^{70}$ These limitations, in addition to increased sensitivity of FIT, have resulted in more common use of FIT over FOBT. ${ }^{72}$ Finally, adherence to annually recommended FOBT/FIT screening is low in the US where most screening is opportunistic..$^{62,73-75}$ In a study of more than a million participants of screening age, adherence to an annual FOBT was found to be $42.1 \%$ for men and $42.9 \%$ for women. ${ }^{73}$ Likewise, the rate of follow-up colonoscopy screening for those who receive positive test results is low, thus negating the value of FOBT/FIT screening in those patients. ${ }^{62}$ However, organizational screening using FIT/FOBT shows an improvement in the annual adherence rate and uptake. ${ }^{76,77}$

\section{Multitarget stool DNA testing}

Multitarget stool DNA (mt-sDNA) testing is a noninvasive screening method designed to detect abnormal DNA and occult blood in stool samples. ${ }^{43,53}$ At present, there is only one commercially available mt-sDNA test (Cologuard ${ }^{\circledR}$; Exact Sciences Corporation, Madison, WI, USA). The test is designed to detect ten DNA-based markers and one human hemoglobin biomarker in stool. Results of the assays used to detect DNA and hemoglobin biomarkers are then combined in a diagnostic algorithm that yields the single composite negative or positive result. If a composite level of abnormal DNA and/or blood from a potential cancerous or precancerous lesion is detected, the test will yield a positive result and the patient should be referred for a diagnostic colonoscopy and removal of lesions if necessary. Alternatively, a negative test result is assigned if the normal internal control DNA is detected and the combined levels of the test biomarkers are below the threshold for detection. In this case, patients should continue with recommended, routine screening. ${ }^{65}$

The clinical sensitivity of the mt-sDNA test was demonstrated in a blinded, cross-sectional, screening study conducted at 90 sites. The study included $>10,000$ asymptomatic, average-risk participants aged $\geq 50$ years and established the performance of this test as compared with FIT and colonoscopy. ${ }^{65}$ In this study, the mt-sDNA test had a sensitivity of $92.3 \%$, detecting 60 of 65 cancers compared to the FIT test sensitivity of $73.8 \%$ that detected 48 of 65 cancers (OC FIT-CHEK; Polymedco, Cortlandt Manor, NY, USA). mt-sDNA test demonstrated superior sensitivity for detecting advanced precancerous lesions, detecting $42.4 \%$ of the subjects with advanced adenomas, $69.2 \%$ 
of the subjects with precancerous lesions with high-grade dysplasia, and $42.4 \%$ of the subjects with SSPs. By contrast, FIT identified $23.8 \%, 46.2 \%$, and $5.1 \%$, respectively. ${ }^{65}$ The specificity (true-negative rate) of mt-sDNA among subjects with findings other than $\mathrm{CRC}$ or advanced precancerous lesions was $86.6 \%$, compared to $94.9 \%$ for FIT. Among subjects with totally negative results on colonoscopy, mt-sDNA had a specificity of $89.8 \%$, compared to $96.4 \%$ for FIT. In patients with a negative test result, the negative predictive value of the mt-sDNA test was extremely high (99.94\%); a negative test result suggests that the likelihood of having a missed CRC was only $0.06 \%$ and the chance of having an advanced adenoma was $5.2 \% .{ }^{63} \mathrm{~A}$ second study assessed the accuracy of mt-sDNA compared to FIT, and the sensitivity and specificity results were similar. ${ }^{78}$

The mt-sDNA test requires a stool sample that is collected by the patient at home and does not require any bowel preparation or changes to medications and diet. ${ }^{65}$ A screening interval of 3 years has been recommended by American Cancer Society guidelines ${ }^{79}$ and has been subsequently supported via data modeling, and the test is reimbursed by Medicare every 3 years. ${ }^{80-82}$ The cost of the test is US $\$ 649$, is covered by many major insurers, and includes all shipping costs and a systematic compliance program that offers patient reminders for screening, handles patient questions, manages patient billing and reimbursement, and provides compliance and tracking records for physicians, all of which may help ease the burden on primary care offices.$^{80}$ Limitations include the relative newness of the test with limited evidence and while it has a high sensitivity that is offset with somewhat less specificity. ${ }^{65}$ However, when evaluating screening tests, it is important to remember that sensitivity is the most important characteristic.

\section{Conclusion}

Precursor lesions of different types typically precede the development of CRC by many years, providing an ample window for early detection via various screening methods. Screening for CRC is a critical part of primary care practice. Primary care practitioners are well positioned to initiate a dialog with patients to discuss the benefits of CRC screening and to provide a comprehensive view of current screening options including the advantages and limitations of each. Offering a variety of screening options, particularly in the context of each patient's wishes and limitations, may increase compliance with screening. ${ }^{46}$ Increased compliance with CRC screening recommendations has the potential to improve patients' health and well-being and to ultimately reduce $\mathrm{CRC}$ morbidity and mortality rates. Regardless of all other factors, the best CRC screening test is the one that is completed in a timely manner.

\section{Acknowledgment}

The author would like to acknowledge Exact Sciences for critical review of the manuscript.

\section{Disclosure}

Dr Simon is a trial investigator and a speaker for Exact Sciences, the manufacturer of Cologuard ${ }^{\circledR}$, and has received honoraria from Exact Sciences for her speaking events. The author reports no other conflicts of interest in this work.

\section{References}

1. American Cancer Society. Colorectal Cancer Facts \& Figures 2011-2013. Atlanta, GA: American Cancer Society; 2011.

2. American Cancer Society. Cancer Facts \& Figures 2015. Atlanta, GA: American Cancer Society; 2015.

3. National Cancer Institute [webpage on the Internet]. Surveillance, Epidemiology, and End Results Program. SEER Stat Fact Sheets: Colon and Rectum Cancer. Available from: http://seer.cancer.gov/statfacts/ html/colorect.html. Accessed March 3, 2016.

4. ACS [webpage on the Internet]. What are the survival rates for colorectal cancer by stage? 2015. Available from: http://www.cancer.org/cancer/ colonandrectumcancer/detailedguide/colorectal-cancer-survival-rates; http://tinyurl.com/grroztx. Accessed March 3, 2016.

5. Mariotto AB, Yabroff KR, Shao Y, Feuer EJ, Brown ML. Projections of the cost of cancer care in the United States: 2010-2020. J Natl Cancer Inst. 2011;103(2):117-128.

6. Lansdorp-Vogelaar I, van Ballegooijen M, Zauber AG, Habbema JD, Kuipers EJ. Effect of rising chemotherapy costs on the cost savings of colorectal cancer screening. J Natl Cancer Inst. 2009;101(30): $1412-1422$

7. Centers for Disease Control and Prevention. Vital signs: colorectal cancer screening test use-United States, 2012. MMWR Morb Mortal Wkly Rep. 2013;62(44):881-888.

8. National Colorectal Cancer Roundtable [webpage on the Internet]. $80 \%$ by 2018. Available from: http://nccrt.org/tools/80-percent-by-2018/80by-2018-press-kit/. Accessed March 3, 2016.

9. Meester RG, Doubeni CA, Zauber AG, et al. Public health impact of achieving $80 \%$ colorectal cancer screening rates in the United States by 2018. Cancer. 2015;121(13):2281-2285.

10. Frank SA. Dynamics of Cancer: Incidence, Inheritance, and Evolution. Princeton (NJ): Princeton University Press; 2007. Chapter 3, Multistage Progression. Available from: http://www.ncbi.nlm.nih.gov/books/ NBK1562/. Accessed June 15, 2016.

11. Stracci F, Zorzi M, Grazzini G. Colorectal cancer screening: tests, strategies, and perspectives. Front Public Health. 2014;2:210.

12. Conteduca V, Sansonno D, Russi S, Dammacco F. Precancerous colorectal lesions (review). Int J Oncol. 2013;43(4):973-984.

13. Yamane L, Scapulatempo-Neto C, Reis RM, Guimarães DP. Serrated pathway in colorectal carcinogenesis. World J Gastroenterol. 2014; 20(10):2634-2640

14. East JE, Vieth M, Rex DK. Serrated lesions in colorectal cancer screening: detection, resection, pathology and surveillance. Gut. 2015; 64(6):991-1000.

15. Snover DC. Update on the serrated pathway to colorectal carcinoma. Hum Pathol. 2011;42(1):1-10.

16. Siegel RL, Ward EM, Jemal A. Trends in colorectal cancer incidence rates in the United States by tumor location and stage, 1992-2008. Cancer Epidemiol Biomarkers Prev. 2012;21(3):411-416. 
17. Lochhead P, Chan AT, Giovannucci E, et al. Progress and opportunities in molecular pathological epidemiology of colorectal premalignant lesions. Am J Gastroenterol. 2014;109(8):1205-1214.

18. Nagy JA, Chang SH, Dvorak AM, Dvorak HF. Why are tumour blood vessels abnormal and why is it important to know? Br J Cancer. 2009; 100(6):865-869.

19. Heinen CD, Schmutte C, Fishel R. DNA repair and tumorigenesis: lessons from hereditary cancer syndromes. Cancer Biol Ther. 2002;1(5): 477-485.

20. Kinzler KW, Vogelstein B. Lessons from hereditary colorectal cancer. Cell. 1996;87(2):159-170.

21. Bateman AC. Pathology of serrated colorectal lesions. J Clin Pathol. 2014;67(10):865-874.

22. Pino MS, Chung DC. The chromosomal instability pathway in colon cancer. Gastroenterology. 2010;138(6):2059-2072.

23. Kang GH. Four molecular subtypes of colorectal cancer and their precursor lesions. Arch Pathol Lab Med. 2011;135(6):698-703.

24. Kambara T, Simms LA, Whitehall VL, et al. BRAF mutation is associated with DNA methylation in serrated polyps and cancers of the colorectum. Gut. 2004;53(8):1137-1144.

25. Loh K, Chia JA, Greco S, et al. Bone morphogenic protein 3 inactivation is an early and frequent event in colorectal cancer development. Genes Chromosomes Cancer. 2008;47(6):449-460.

26. Melotte V, Lentjes MH, van den Bosch SM, et al. N-Myc downstreamregulated gene 4 (NDRG4): a candidate tumor suppressor gene and potential biomarker for colorectal cancer. J Natl Cancer Inst. 2009;101(13): 916-927.

27. Boland CR, Goel A. Microsatellite instability in colorectal cancer. Gastroenterology. 2010;138(6):2073.e3-2087.e3.

28. O'Brien MJ, Yang S, Mack C, et al. Comparison of microsatellite instability, $\mathrm{CpG}$ island methylation phenotype, BRAF and KRAS status in serrated polyps and traditional adenomas indicates separate pathways to distinct colorectal carcinoma end points. Am J Surg Pathol. 2006;30(12):1491-1501.

29. Koinuma K, Shitoh K, Miyakura Y, et al. Mutations of BRAF are associated with extensive hMLH1 promoter methylation in sporadic colorectal carcinomas. Int J Cancer. 2004;108(2):237-242.

30. Ling BS, Moskowitz MA, Wachs D, Pearson B, Schroy PC. Attitudes toward colorectal cancer screening tests. J Gen Intern Med. 2001; 16(12):822-830.

31. Agency for Healthcare Research and Quality. Clinical Summaries of Recommendations for Adults: Colorectal Cancer. Guide to Clinical Preventive Services. Rockville, MD: Agency for Healthcare Research and Quality; 2014.

32. Regula J, Rupinski M, Kraszewska E, et al. Colonoscopy in colorectalcancer screening for detection of advanced neoplasia. $N$ Engl J Med 2006;355(18):1863-1872.

33. Imperiale TF, Wagner DR, Lin CY, Larkin GN, Rogge JD, Ransohoff DF. Risk of advanced proximal neoplasms in asymptomatic adults according to the distal colorectal findings. N Engl J Med. 2000; 343(3):169-174

34. Lieberman DA, Weiss DG, Bond JH, Ahnen DJ, Garewal H, Chejfec G. Use of colonoscopy to screen asymptomatic adults for colorecta cancer. Veterans Affairs Cooperative Study Group 380. N Engl J Med. 2000;343(3):162-168.

35. Schoenfeld P, Cash B, Flood A, et al. Colonoscopic screening of averagerisk women for colorectal neoplasia. $N$ Engl J Med. 2005;352(20): 2061-2068.

36. Cotton PB, Durkalski VL, Pineau BC, et al. Computed tomographic colonography (virtual colonoscopy): a multicenter comparison with standard colonoscopy for detection of colorectal neoplasia. JAMA. 2004; 291(14):1713-1719.

37. Lieberman DA, Holub J, Eisen G, Kraemer D, Morris CD. Prevalence of polyps greater than $9 \mathrm{~mm}$ in a consortium of diverse clinical practice settings in the United States. Clin Gastroenterol Hepatol. 2005; 3(8):798-805.
38. Pickhardt PJ, Choi JR, Hwang I, et al. Computed tomographic virtual colonoscopy to screen for colorectal neoplasia in asymptomatic adults. N Engl J Med. 2003;349(23):2191-2200.

39. Rockey DC, Paulson E, Niedzwiecki D, et al. Analysis of air contrast barium enema, computed tomographic colonography, and colonoscopy: prospective comparison. Lancet. 2005;365(9456):305-311.

40. Baxter NN, Goldwasser MA, Paszat LF, Saskin R, Urbach DR, Rabeneck L. Association of colonoscopy and death from colorectal cancer. Ann Intern Med. 2009;150(1):1-8.

41. Müller AD, Sonnenberg A. Prevention of colorectal cancer by flexible endoscopy and polypectomy. A case-control study of 32,702 veterans. Ann Intern Med. 1995;123(12):904-910.

42. Singh H, Turner D, Xue L, Targownik LE, Bernstein CN. Risk of developing colorectal cancer following a negative colonoscopy examination: evidence for a 10-year interval between colonoscopies JAMA. 2006;295(20):2366-2373.

43. Levin B, Lieberman DA, McFarland B, et al. Screening and surveillance for the early detection of colorectal cancer and adenomatous polyps, 2008: a joint guideline from the American Cancer Society, the US Multi-Society Task Force on Colorectal Cancer, and the American College of Radiology. Gastroenterology. 2008;134(5):1570-1595.

44. Wexner SD, Beck DE, Baron TH, et al. A consensus document on bowel preparation before colonoscopy: prepared by a task force from the American Society of Colon and Rectal Surgeons (ASCRS), the American Society for Gastrointestinal Endoscopy (ASGE), and the Society of American Gastrointestinal and Endoscopic Surgeons (SAGES). Gastrointest Endosc. 2006;63(7):894-909.

45. Cooper GS, Kou TD, Rex DK. Complications following colonoscopy with anesthesia assistance: a population-based analysis. JAMA Intern Med. 2013;173(7):551-556.

46. Inadomi JM, Vijan S, Janz NK, et al. Adherence to colorectal cancer screening: a randomized clinical trial of competing strategies. Arch Intern Med. 2012;172(7):575-582.

47. Soetikno RM, Kaltenbach T, Rouse RV, et al. Prevalence of nonpolypoid (flat and depressed) colorectal neoplasms in asymptomatic and symptomatic adults. JAMA. 2008;299(9):1027-1035.

48. Corley DA, Jensen CD, Marks AR, et al. Adenoma detection rate and risk of colorectal cancer and death. $N$ Engl J Med. 2014;370(26): 1298-1306.

49. Patel SG, Ahnen DJ. Prevention of interval colorectal cancers: what every clinician needs to know. Clin Gastroenterol Hepatol. 2014;12(1):7-15.

50. Samadder NJ, Curtin K, Tuohy TM, et al. Characteristics of missed or interval colorectal cancer and patient survival: a population-based study. Gastroenterology. 2014;146(4):950-960.

51. Selby JV, Friedman GD, Quesenberry CP Jr, Weiss NS. A case-control study of screening sigmoidoscopy and mortality from colorectal cancer. N Engl J Med. 1992;326(10):653-657.

52. Hoff G, Grotmol T, Skovlund E, Bretthauer M; Norwegian Colorectal Cancer Prevention Study Group. Risk of colorectal cancer seven years after flexible sigmoidoscopy screening: randomised controlled trial. BMJ. 2009;338:b1846.

53. Binefa G, Rodríguez-Moranta F, Teule A, Medina-Hayas M. Colorectal cancer: from prevention to personalized medicine. World J Gastroenterol. 2014;20(22):6786-6808.

54. Johnson CD, Chen MH, Toledano AY, et al. Accuracy of CT colonography for detection of large adenomas and cancers. $N$ Engl J Med. 2008;359(12):1207-1217.

55. U.S. Preventive Services Task Force. Screening for colorectal cancer: U.S. Preventive Services Task Force recommendation statement. Ann Intern Med. 2008;149(9):627-637.

56. Whitlock EP, Lin JS, Liles E, Beil TL, Fu R. Screening for colorectal cancer: a targeted, updated systematic review for the U.S. Preventive Services Task Force. Ann Intern Med. 2008;149(9):638-658.

57. Sali L, Mascalchi M, Falchini M, et al; SAVE Study Investigators. Reduced and full-preparation CT colonography, fecal immunochemical test, and colonoscopy for population screening of colorectal cancer: a randomized trial. J Natl Cancer Inst. 2016;108(2). 
58. Stoop EM, de Haan MC, de Wijkerslooth TR, et al. Participation and yield of colonoscopy versus non-cathartic CT colonography in population-based screening for colorectal cancer: a randomised controlled trial. Lancet Oncol. 2012;13(1):55-64.

59. ASGE Technology Committee; Farraye FA, Adler DG, et al. Update on CT colonography. Gastrointest Endosc. 2009;69(3 Pt 1):393-398.

60. Centers for Medicare and Medicaid Services. Decision Memo for Screening Computed Tomography Colonography (CTC) for Colorectal Cancer (CAG-00396N). Baltimore, MD: Centers for Medicare and Medicaid Services; 2009.

61. de Haan MC, Pickhardt PJ, Stoker J. CT colonography: accuracy, acceptance, safety and position in organised population screening. Gut. 2015;64(2):342-350.

62. Lieberman DA. Clinical practice. Screening for colorectal cancer. N Engl J Med. 2009;361(12):1179-1187.

63. Canadian Agency for Drugs and Technologies in Health. Fecal immunochemical tests for colorectal cancer screening: a systematic review. CADTH Technol Overv. 2010;1(3):e0117.

64. de Wijkerslooth TR, Stoop EM, Bossuyt PM, et al. Immunochemical fecal occult blood testing is equally sensitive for proximal and distal advanced neoplasia. Am J Gastroenterol. 2012;107(10):1570-1578.

65. Imperiale TF, Ransohoff DF, Itzkowitz SH, et al. Multitarget stool DNA testing for colorectal-cancer screening. N Engl J Med. 2014;370(14): 1287-1297.

66. Lee JK, Liles EG, Bent S, Levin TR, Corley DA. Accuracy of fecal immunochemical tests for colorectal cancer: systematic review and meta-analysis. Ann Intern Med. 2014;160(3):171.

67. Imperiale TF, Ransohoff DF, Itzkowitz SH, Turnbull BA, Ross ME; Colorectal Cancer Study Group. Fecal DNA versus fecal occult blood for colorectal-cancer screening in an average-risk population. $N \mathrm{Engl}$ J Med. 2004;351(26):2704-2714.

68. Ahlquist DA, Sargent DJ, Loprinzi CL, et al. Stool DNA and occult blood testing for screen detection of colorectal neoplasia. Ann Intern Med. 2008;149(7):441-450, W81.

69. Kronborg O, Fenger C, Olsen J, Jørgensen OD, Søndergaard O. Randomised study of screening for colorectal cancer with faecal-occultblood test. Lancet. 1996;348(9040):1467-1471.

70. Mandel JS, Bond JH, Church TR, et al. Reducing mortality from colorectal cancer by screening for fecal occult blood. Minnesota Colon Cancer Control Study. N Engl J Med. 1993;328(19):1365-1371.
71. Hardcastle JD, Chamberlain JO, Robinson $\mathrm{MH}$, et al. Randomised controlled trial of faecal-occult-blood screening for colorectal cancer. Lancet. 1996;348(9040):1472-1477.

72. Young GP, Symonds EL, Allison JE, et al. Advances in fecal occult blood tests: the FIT revolution. Dig Dis Sci. 2015;60(3):609-622.

73. Gellad ZF, Stechuchak KM, Fisher DA, et al. Longitudinal adherence to fecal occult blood testing impacts colorectal cancer screening quality. Am J Gastroenterol. 2011;106(6):1125-1134.

74. Liang PS, Wheat CL, Abhat A, et al. Adherence to competing strategies for colorectal cancer screening over 3 years. Am J Gastroenterol. 2016;111(1):105-114.

75. Jensen CD, Corley DA, Quinn VP, et al. Fecal immunochemical test program performance over 4 rounds of annual screening: a retrospective cohort study. Ann Intern Med. 2016;164(7):456-463.

76. Steele RJ, McDonald PJ, Digby J, et al. Clinical outcomes using a faecal immunochemical test for haemoglobin as a first-line test in a national programme constrained by colonoscopy capacity. United European Gastroenterol J. 2013;1(3):198-205.

77. Kapidzic A, Grobbee EJ, Hol L, et al. Attendance and yield over three rounds of population-based fecal immunochemical test screening. Am J Gastroenterol. 2014;109(8):1257-1264.

78. Redwood DG, Asay ED, Blake ID, et al. Stool DNA testing for screening detection of colorectal Neoplasia in Alaska native people. Mayo Clin Proc. 2016;91(1):61-70.

79. American Cancer Society. Colorectal Cancer Prevention and Early Detection. Atlanta, GA: American Cancer Society; 2016.

80. Berger BM, Schroy PC 3rd, Rosenberg JL, et al. Colorectal cancer screening using stool DNA analysis in clinical practice: early clinical experience with respect to patient acceptance and colonoscopic follow-up of abnormal tests. Clin Colorectal Cancer. 2006;5(5):338-343.

81. Berger BM, Schroy PC 3rd, Dinh T. Screening for colorectal cancer using a multitarget stool DNA test: modeling the impact of the inter-test interval on clinical effectiveness. Clin Colorectal Cancer. Epub 2015 Dec 18. doi:10.1016/j.clcc.2015.12.003.

82. Berger BM, Parton MA, Levin B. USPSTF CRC screening guidelines: an extended look at multi-year interval testing. Am J Manag Care. 2016; 22(2):e77-e81.
Clinical Interventions in Aging

\section{Publish your work in this journal}

Clinical Interventions in Aging is an international, peer-reviewed journal focusing on evidence-based reports on the value or lack thereof of treatments intended to prevent or delay the onset of maladaptive correlates of aging in human beings. This journal is indexed on PubMed Central, MedLine,

\section{Dovepress}

CAS, Scopus and the Elsevier Bibliographic databases. The manuscript management system is completely online and includes a very quick and fair peer-review system, which is all easy to use. Visit http://www.dovepress. com/testimonials.php to read real quotes from published authors. 